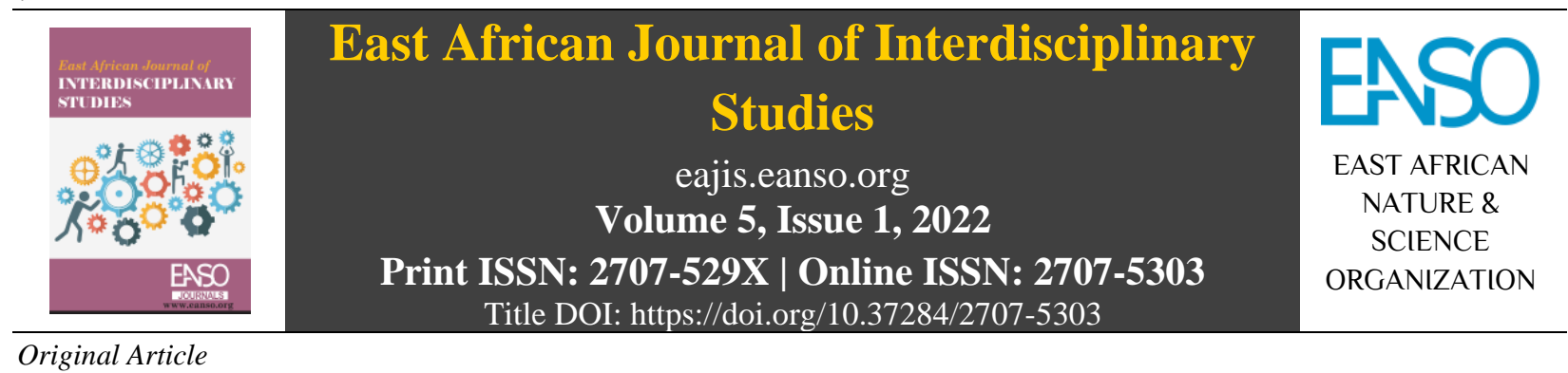

\title{
Relationship between Tutor Confidence and ICT Integration in Primary Teacher Training Colleges in Kenya.
}

\section{Bernard Chemwei ${ }^{1 *}$}

${ }^{1}$ Kirinyaga University P.O Box 143 - 10300, Kerugoya, Kenya.

* ORCID: https://orcid.org/0000-0002-1224-5561. Author for Correspondence email: bchemwei@ yahoo.com

Article DOI: https://doi.org/10.37284/eajis.5.1.524

\section{Date Published: ABSTRACT}

11 January 2021 Despite increases in computer access and technology training, ICT is not adequately being used to support instruction in teacher education institutions.

Keywords: Unless teachers improve their ability to use existing technology, they will encounter various difficulties. One of the most notable of these difficulties is that

Confidence, they cannot respond to the expectations of their students. Research has shown that

$I C T$, the self-confidence of teachers affects their use of technology in instruction. The study assessed the confidence of tutors in primary teacher training colleges

Integration,

Teaching, regarding the integration of ICT in the teaching and learning practice in Kenya.

Teacher Training There are a number of ICT projects that are equipping Kenyan institutions of colleges, literature on studies among tutors is so scanty, leaving a noticeable gap in the Kenya, literature about tutors' level of ICT integration in instruction. The study sought to Tutors. establish the relationship between tutor confidence and their level of ICT integration teacher training colleges in Kenya. A cross-sectional survey was conducted to investigate tutors' confidence in the use of ICT in teaching. The simple random sampling technique was used to select six teacher training colleges in Kenya and 169 respondents who participated in the study. Data was collected using a questionnaire and an interview schedule. The data collected was analysed descriptively for frequencies, means, standard deviation, and percentages. The significance of relationships and differences of variables were tested using Pearson moment Correlation and Regression analysis. Results indicated that there is a low level of ICT integration in teaching in all teacher training colleges. A significant relationship was found between the tutor's confidence and their level of ICT integration in teaching $(\beta 3=0.535, p<0.05)$. It was thus recommended that: College tutors should be given adequate exposure for them to be able to utilize ICT facilities in their classrooms. Colleges should also computerize most activities by buying computerized software within departments. This will compel most tutors to acquire the requisite skills. The ministry of education should also embrace ICT and demand professional documents from college tutors be typed and sent online.

1| This work is licensed under a Creative Commons Attribution 4.0 International License. 
East African Journal of Interdisciplinary Studies, Volume 5, Issue 1, 2022

Article DOI: https://doi.org/10.37284/eajis.5.1.524

\section{APA CITATION}

Chemwei, B., (2022). Relationship between Tutor Confidence and ICT Integration in Primary Teacher Training Colleges in Kenya. East African Journal of Interdisciplinary Studies, 5(1), 1-7. https://doi.org/10.37284/eajis.5.1.524

\section{CHICAGO CITATION}

Chemwei, Bernard. 2022. "Relationship between Tutor Confidence and ICT Integration in Primary Teacher Training Colleges in Kenya”. East African Journal of Interdisciplinary Studies 5 (1), 1-7. https://doi.org/10.37284/eajis.5.1.524.

\section{HARVARD CITATION}

Chemwei, B., (2022) "Relationship between Tutor Confidence and ICT Integration in Primary Teacher Training Colleges in Kenya”, East African Journal of Interdisciplinary Studies, 5(1), pp. 1-7. doi: 10.37284/eajis.5.1.524.

\section{IEEE CITATION}

B. Chemwei, "Relationship between Tutor Confidence and ICT Integration in Primary Teacher Training Colleges in Kenya", EAJIS, vol. 5, no. 1, pp. 1-7, Jan. 2022.

\section{MLA CITATION}

Chemwei, Bernard., "Relationship between Tutor Confidence and ICT Integration in Primary Teacher Training Colleges in Kenya". East African Journal of Interdisciplinary Studies, Vol. 5, no. 1, Jan. 2022, pp. 1-7, doi:10.37284/eajis.5.1.524.

\section{INTRODUCTION}

The study assessed the level of ICTs' integration into teaching by college tutors in Kenya. ICT refers to technologies that provide access to information through telecommunication (Ratheeswari, 2018). Today, world economies are driven by information and knowledge. The world is in need of a workforce with ICT competencies.

In order to produce a workforce that is capable of fitting into the knowledge-driven society, the training of teachers in Primary Teachers Colleges was to integrate Information and Communication Technologies (ICTs) in teaching and learning. In Kenya, the government has put in place ICT policies to guide the use of ICTs in teacher training as a proper way of imparting in teacher trainees the skills needed for preparing trainee teachers with the right training. Among the policies was providing extensive training to the tutors on the use of ICTs in teaching and learning.

Indeed, a number of ICT projects are equipping Kenyan institutions of learning with computers and establishing internet connectivity. But the body of literature on studies among teacher-trainers is so scanty, leaving a noticeable gap in the literature about tutors' level of ICTs integration into instruction. The existing research studies have looked at the situation from the perspective of the students and student teachers, leaving out the teachers and tutors (Menjo, 2007; Migwi, 2009; Ndawula, 2009; Wakhaya, 2010). Yet the views of tutors as the key implementers of innovations should constitute a vital form of analysis into the effectiveness of information and communication technology. Research has shown that the selfconfidence and competence of teachers affected their using technology in instruction (Peralta and Costa, 2007; Oral, 2008). It has also shown that tutors were not good models on the use of technology in teacher training, and did not require students to use technology (Mukuna, 2013; Muyaka \& Gathara, 2013). It is common knowledge that the skills that we invest in the teachers get replicated among students while they teach. Since teachers remain important in meeting Kenya's Vision 2030, the question of who prepares them becomes not only important but worthy of investigation. For Kenya to achieve Vision 2030, learning institutions especially teacher education institutions have a critical role to play. The people entrusted with the responsibilities are the tutors.

Barasa (2021) notes that the Ministry of Education, Science, and Technology planned to set up one computer laboratory for each of the 25,000 public primary schools across Kenya, which is thought to be more feasible than a laptop per child in public primary schools. This is because it is believed that the laptop project failed due to a lack of funds, electricity, teacher training, storage, and digital devices to run the digital programme in schools (Nyaundi, 2019). 


\section{Tutors' Self Confidence}

Tutor confidence refers both to the teacher trainers' perceived likelihood of success in using ICT for educational purposes and on how far he or she perceives success as being under his or her control (Bandura, 1997). According to Keller (1987), confidence has different components: interest (refers to the attention factors in the environment; relevance (refers to goal-oriented activities; expectancy (refers to one's own expectation for being successful) and outcomes (refers to the reinforcement value of instruction, here, of the use of technology in learning).

In the context of technology integration, selfconfidence can be interpreted as "How effective am I as a teacher when using technology to teach?" According to Sang et al. (2010), it seems that a few teachers intend to implement ICTs in their teaching. Furthermore, Black (2009) shows research results where $20 \%$ of teachers identify their lack of use to limited expertise and confidence. Self-confidence is becoming an obstacle in integrating ICT into key learning areas (KLA). How can teachers be supported to turn the potential of ICT into practice? How can their efforts be made effective? These questions need to be addressed, with professional networking amongst teachers providing a possible solution.

In actual fact, teacher self-confidence is determined by the achievement - beliefs such as "I can do these tasks" and "how well have I done these tasks in the past". It is immediately obvious, then, that teachers' past experience in using technology affects their beliefs about themselves as effective teachers. The experience in both learning with technology and teaching with technology greatly affects the teacher's confidence in integrating technology in instruction. Confidence is highly related to technology use (Sang et al., 2010).

\section{Statement of the Problem}

There is increasing pressure from policy makers for educators in teacher education institutions to graduate teachers who are skilled, confident, and competent in using information and communication technologies for their personal and professional lives. This is due to the important role played by
ICTs in enhancing teaching and learning as well as deal with the challenges of access, quality, and relevance faced by Kenya's education system. All teachers in Kenyan primary schools were required to be ICT literate by 2015 to implement the policy on ICT use. Pre-service teacher trainees were also expected to acquire ICT competencies within the same period (RoK, 2018). Despite the government directive that teachers should use ICT in teaching and learning, tutors in primary teacher education institutions were slow to embrace ICT in their teaching, raising questions about teachers' competence and confidence in using ICT for teaching. For any change geared to meet the learning needs for all to succeed, it must first find expression in the teaching institutions. Hence training of teachers with competence is key in the use of ICTs in schools.

For this reason, tutors in teacher training institutions are expected to model appropriate uses of ICTs in instruction in order to equip future teachers with the necessary knowledge, skills, and attitudes to effectively use these skills in curriculum delivery and also in their working lives. In effect, a government project that provided ICT tablets to primary schools for teaching and learning failed at its infancy stage (Nyaundi, 2019). Some of the reasons that were given for the project failure include: poor training of teachers, lack of electrical power, and power disconnections due to nonpayment of electricity bills.

Furthermore, the integration of ICT in teacher education has been slow, giving rise to the notion that there are critical factors that influence integration levels of ICT in teacher training colleges. One of the factors that influence tutors to integrate ICT in teaching is their confidence levels in using ICT (Jaikaran-Doe et al., 2016; Peralta \& Costa, 2007; Oral, 2008). Since there seems to be a link between such factor and the level to which tutors integrate ICT into teaching, the study was designed to investigate the extent to which tutor confidence influence the level of ICT integration in primary teacher training colleges.

\section{Purpose of the study}

The main purpose of the study was to examine the relationship between tutor confidence and their 
level of ICT Integration in Primary Teacher Training Colleges in Kenya.

\section{MATERIALS AND METHODS}

This study employed a descriptive survey. A descriptive survey focuses on determining the status of a defined population with respect to certain variables. They are flexible in tackling a range of problems related to attitudes, perspectives, and beliefs of participants and can employ written questionnaires or interviews (McMillan, 2004).

The study was carried out in six public primary teacher training colleges in Kenya. PTTCs were chosen because they represent the basic teacher education institutions in the country. Furthermore, PTTCs made a good research population because of the Government's commitment to improve PTE to make it more relevant to the needs of the country in tandem with international trends (MOE, 2005). These colleges which offered certificate in primary teacher education are Eregi, Mosoriot, Kilimambogo, Muranga, Machakos, and Baringo TTCs. Primary TTCs were chosen because there have been initiatives by the Government to integrate ICTs in teaching in teacher education.

The target population for the study consisted of the entire tutors in Kenya. The researcher utilized the 18 fully operational primary school teacher training colleges as the population of the study. All these colleges have computer laboratories and are making efforts to improve their ICT capacity. On average, teachers' colleges admit 600 students annually for a two-year certificate in primary teacher education. Tutors in these colleges range from 29 to 90 . At the time of this study, there were 1,299 tutors in the public TTCs (ROK, 2005b). Tutors were selected because they are directly involved in the training of primary school teachers in their respective institutions. They are thus the actual implementers of ICT integration policies in teacher education programmes. Additionally, 36 heads of the various departments and 6 principals, one from each TTC were also interviewed as key informants and provided an in-depth understanding of issues of concern to the study.

The author decided to use the simple random sampling technique since the population was within the reach of statistical evaluation. First, a sample of six teachers' colleges was picked from the 18 colleges forming the research population. This was $30 \%$ of the total number of primary teachers' colleges in the country. The six colleges were picked at random using the balloting method. In these colleges, the total number of tutors was 418 . From this total population, the study used Slovin's formula to determine the sample size. It was found that a sample of 204 tutors would be needed to accurately represent the population in question. The proportionate sampling technique was then used to select two hundred and four participants who served as respondents chosen from the tutors across the colleges to constitute the sample.

Researchers prefer using methods that provide high accuracy, generalisability, and explanatory power, with low cost, rapid speed, and maximum management and administrative convenience. Basing on this fact, a combination of the following research instruments was used in this study for complementary purposes: a questionnaire and an interview schedule. Descriptive statistics using frequencies, means, standard deviations, tables, and percentages were used for the data on the level of ICT integration into teaching by college tutors in TTCs.

The percentages were also used to answer one question that asked the levels of tutors' confidence in using ICTs in TTCs. A correlation was used to determine if a significant relationship existed between the level of ICT integration and tutor confidence in integrating of ICTs. Regression analysis was used to determine whether tutor confidence can be used to predict ICT integration in TTCs. In addition, the tutors' demographic variables were designated as independent variables while their perceived level of ICT integration into teaching is the dependent variable in the analysis. The significance level was set at 0.05 . All statistical analyses were computed using the statistical packages for social sciences. Information from interviews was recorded and transcribed verbatim. A qualitative assessment procedure was applied to the respondents' answers. The text was read and an interpretive statement that captures the essence of the respondent's quote was written. 


\section{RESULTS AND DISCUSSION}

\section{Description of Tutors' Confidence Level}

The data presented in Table 1 indicates that, with regard to tutors' confidence levels, $61.5 \%$ agreed and strongly agreed that they alter the way they use computers as an instructional tool as they research on teaching and learning and gain new knowledge. However, it is only $42.2 \%$ who agreed and strongly agreed that it is not easy for them to develop student-centered integrated curriculum units that use computers. The results further reported that $44.3 \%$ agreed and strongly agreed that they have expanded the horizon of instructional computing to their students using available computers; $47.8 \%$ agreed and strongly agreed that they use integrated curriculum units that emphasize problem-solving; $48.4 \%$ cannot show others how to integrate computers in teaching; $63.2 \%$ agreed and strongly agreed that they are confident of what they are doing when using computers; $45.7 \%$ are unable able to perform translations, compress image files and work across platforms.

Table 1: Tutors' Confidence in ICT Integration

\begin{tabular}{llllll}
\hline & SA & A & U & D & SD \\
\hline Alter use of computers & 23.6 & 37.9 & 23.3 & 9.9 & 5.6 \\
Develop student-centred, integrated curriculum units & 9.3 & 32.9 & 23.0 & 24.8 & 9.9 \\
Expanded the horizon of instructional computing & 16.6 & 27.7 & 27.4 & 21.7 & 7.0 \\
Use integrated curriculum & 16.7 & 31.1 & 23.1 & 21.8 & 7.1 \\
No ability to show others how to integrate ICT & 10.7 & 37.7 & 19.5 & 15.7 & 16.4 \\
Confident of what I am doing when using computers & 24.5 & 38.7 & 16.8 & 16.1 & 13.1 \\
Unable to perform translations and compress images & 16.3 & 29.4 & 19.4 & 21.9 & 13.1 \\
\hline
\end{tabular}

From this discussion, it is evident that tutors have moderate confidence in integrating ICTs into their teaching practice. More emphasis should be put on the development of their computer confidence. This can be done through training.

\section{Hypothesis Test Results}

From the hypothesis test findings, the Pearson Moment Correlation Coefficient between the level of ICT integration into teaching by the tutors and their confidence levels was $0.535^{* *}$. This indicates a positive relationship between the sets of variables. Furthermore, the results of the regression analysis are consistent with the results of the Pearson moment correlation, indicating a significant standardized regression coefficient $(b=0.155 t=$ 2.677, $p<.05$ ) between the level of ICT integration by tutors and their confidence in ICTs. From the hypothesis, there is a significant correlation between the level of ICT integration and tutors' confidence, and the null hypothesis is rejected. Indeed, tutor confidence explains 15.5 per cent of the differences in ICT integration in teaching.

Interviews with principals and heads of departments confirmed that tutors in ICT and Science departments were quite confident in integrating ICT into their teaching. It was observed that most of them had the requisite skills for integration and had more access to computers than tutors in other departments. This confirms the survey findings in that the ICT and Science departments were ahead of the others in integration.

\section{CONCLUSION AND RECOMMENDATIONS}

While the use of ICT in teaching and learning can transform pedagogical practices in teacher education, it was observed that ICT is not an integrated resource within teaching activities. Tutors use ICT without a full understanding of learning principles. While some know practices in how to use computers, they hardly use them in the classroom with teacher trainees. Perhaps it can be said that ICT has not significantly changed the attitudes, roles, and ways of teaching and learning. It was evident there were few competent tutors in using ICT for instruction. As such, there is a need to constantly train tutors in ICT integration. This is because enabling tutors to use technology lies in the teacher education schools where new tutors and teachers are trained. 
From the study findings, it was found that there is a significant relationship between tutors' confidence and their level of ICTs integration. It can be concluded that tutors' confidence is a positive predictive component to ICT integration into teaching. This means that tutor confidence influences the extent to which they integrate ICTs in teaching. As such, emphasis should be put on the development of tutor confidence in TTCs.

Tutors were found to be confident in ICT integration. But this confidence was mainly exuded by tutors in the ICT and Science departments. This is because they have better requisite skills as a result of more exposure to ICT training than the other tutors.

Considering the findings, the study recommends training and ongoing support of tutors in all specific ICT technologies and their pedagogical uses to influence their confidence to integrate them in curriculum delivery. Tutors in all departments should be given adequate exposure for them to be able to utilize these ICT facilities in their classrooms. Colleges should also computerize most activities in their institutions. This will compel most tutors to acquire the requisite skills to be in tandem with the new development. Furthermore, all college tutors should be encouraged to present their professional records through ICT. Tutors and teacher trainees should be involved in research activities projects relating to the integration of ICT in real teaching and learning situations. In addition, more laptops and computers should be available for use by both tutors and teacher trainees.

\section{REFERENCES}

Bandura, A. (1997). Self-efficacy: The exercise of control. New York. W.H. Freeman.

Barasa, L.P. (2021). Digitalization in teaching and education in Kenya: Digitalization, the future of work and he teaching profession project. International Labour organization. Geneva: Sectoral Policies Department.

Black, G. (2009). This changing world: technology, teaching and learning. Teacher, (203), 16-19.

Jaikaran-Doe, S., Fluck, A., \& Hay, I. (2016). Exploring teachers' confidence to integrate technology in Trinidad and Tobago. In Australian Association for Research in Education Conference 2016 (pp. 1-11).

Keller, J. M. (1987). Development and use of the ARCS model of instructional design. Journal of instructional development, 10(3), 2-10.

McMillan, J. (2004). Educational research: Fundamentals for the consumer (4 ta ed.). EEUU: Pearson Education.

Menjo, D. K. (2007). Application of IT to school administration: A study of the experiences of secondary school administrators and teachers in Nandi North, Kenya. Unpublished M. Phil. Thesis). Moi University, Eldoret.

Migwi, C. N. (2009). An Assessment of Public Secondary School Teachers Preparedness in integrating ICT for instruction: A case of Ruiru Division, Thika District. Unpublished Research project, Kenyatta University.

Ministry of Education (MOE) (2005). Information and communication technology (ICTs) option paper. Retrieved from http://www.education.go .ke.

Mukuna, T. E. (2013). Integration of ICT into teacher training and professional development in Kenya.Makerere Journal of Higher Education, 5(1), 3-21.

Muyaka, J., \& Gathara, P. M. (2013). Tutor ICT Skills and the Realisation of Kenya's Vision 2030. Msingi Journal, 1(1), 317-349.

Ndawula, S. (2009). Internet for Academic Information: Attitudes of undergraduate students in Kyambogo University, Uganda. Unpublished PhD Thesis, Moi University.

Nyaundi, L. (2019). Why Uhuru's flagship laptop project crashed. The Star, 22.

Oral, B. (2008). The evaluation of the student teachers' attitudes toward Internet and democracy. Computers \& Education, 50(1), 437-445.

Peralta, H., \& Costata, F. A. (2007). Teachers' competence and confidence regarding the use of 
ICT. Sísifo-Educational Sciences Journal, 7584.

Ratheeswari, K. (2018). Information communicatio $\mathrm{n}$ technology in education. Journal of Applied and Advanced research, 3(1), 45-47.

Republic of Kenya (2018). Ministry of Education: Sessional Paper of 2018 on Reforming Education and Training for Sustainable Development. Nairobi: Government Press.

Republic of Kenya (ROK) (2005b). Kenya education sector support programme 2005-2010. Delivering quality education and training to all Kenyans. Nairobi: Government Printers.

Sang, G., Valcke, M., Van Braak, J., \& Tondeur, J. (2010). Student teachers' thinking processes and ICT integration: Predictors of prospective teaching behaviors with educational technology. Computers \& Education, 54(1), 103-112.

Wakhaya, M. (2010). Influence of the use of ICT on teaching and learning mathematics in secondary schools: A case study of Nairobi Province, Kenya (Unpublished Masters project report). University of Nairobi, Nairobi.

7| This work is licensed under a Creative Commons Attribution 4.0 International License. 